\title{
BMJ Open Correlation of mesolevel characteristics of the healthcare system and socioeconomic inequality in healthcare use: a scoping review protocol
}

Anna Novelli (D) , ${ }^{1,2}$ Wiebke Schüttig (D) , ${ }^{1,2}$ Jacob Spallek, ${ }^{3}$ Benjamin Wachtler (D) , Katharina Diehl (D) , ${ }^{5}$ Irene Moor (D) , ${ }^{6}$ Matthias Richter, ${ }^{6}$ Nico Dragano (D) , Leonie Sundmacher (i) ${ }^{2}$

To cite: Novelli A, Schüttig W, Spallek J, et al. Correlation of mesolevel characteristics of the healthcare system and socioeconomic inequality in healthcare use: a scoping review protocol. BMJ Open 2021;11:e044301. doi:10.1136/ bmjopen-2020-044301

- Prepublication history and additional materials for this paper are available online. To view these files, please visit the journal online (http://dx.doi. org/10.1136/bmjopen-2020044301).

Received 29 August 2020 Revised 07 December 2020 Accepted 18 December 2020

Check for updates

(C) Author(s) (or their employer(s)) 2021. Re-use permitted under CC BY-NC. No commercial re-use. See rights and permissions. Published by BMJ.

For numbered affiliations see end of article.

Correspondence to

Anna Novelli;

anna.novelli@tum.de

\section{ABSTRACT}

Introduction Although the impact of macrolevel characteristics of health systems on socioeconomic inequity in health has been studied extensively, the impact of access characteristics on a smaller scale of health systems has received less attention. These mesolevel characteristics can influence access to healthcare and might have the potential to moderate or aggravate socioeconomic inequity in healthcare use. This scoping review aims to map the existing evidence of the association of socioeconomic inequity in healthcare use and mesolevel access characteristics of the health system. Methods and analysis In conducting the scoping review, we follow the Preferred Reporting Items for Systematic Review and Meta-Analysis Protocols Extension for Scoping Reviews. The search will be carried out in four scientific databases: MEDLINE (via PubMed), Web of Science, Scopus and PsycINF0. Main eligibility criteria are inclusion in the analysis of a measure of socioeconomic position, a measure of individual healthcare use and a mesolevel determinant of access to healthcare services. The selection process consists of two consecutive screening stages (first: title/abstract; second: full text). At both stages, two reviewers independently assess the eligibility of studies. In case of disagreement, a third reviewer will be involved. Cohen's kappa will be calculated to report inter-rater agreement between reviewers. Results are synthesised narratively, as a high heterogeneity of studies is expected.

Ethics and dissemination No primary data are collected for the presented scoping review. Therefore, ethical approval is not necessary. The scoping review will be published in an international peer-reviewed journal, and findings will be presented on national and international conferences.

\section{INTRODUCTION}

The existence of a social gradient in health is undisputed: lower levels of socioeconomic position (SEP) are associated with higher levels of morbidity and mortality. ${ }^{1}$ Similarly acknowledged is the fact that the design and management of health systems are crucial in

\section{Strengths and limitations of this study}

- This protocol describes the first scoping review focusing on the association of socioeconomic inequality in healthcare use and mesolevel access characteristics of the healthcare system.

- The proposed scoping review adopts a broad scope in order to identify any mesolevel factors that might moderate, aggravate or correlate with socioeconomic inequity in healthcare use

- Only studies that include a measure of socioeconomic position, a measure of healthcare use and mesolevel access characteristics of the health system will be eligible for review.

- The proposed scoping review is limited to studies from high-income countries to increase comparability of findings and, thus, will not capture evidence from middle-income and low-income countries.

achieving health equity. ${ }^{2}$ In recent decades, a large body of research has focused on identifying health system structures and elements addressing health equity. The discourse on equity and inequity in health and the role of health systems were further enhanced by multiple and international policy actions, for example, the establishment of the WHO's Health System Knowledge Network, ${ }^{2}$ or the definition and increasing use of concepts such as universal health coverage. ${ }^{4}$ This research and action ultimately reveal and emphasise the potential and also the responsibility of health systems to contribute to achieving health equity. ${ }^{235} \mathrm{~A}$ key concept in the context of health equity is 'access to healthcare'. Equity in access, as highlighted in the definition of universal health coverage ${ }^{67}$ represents the premise for equity in health. ${ }^{6-11}$ In evaluating and analysing equity in access and the role of health systems at this, 'healthcare use' plays a crucial role. ${ }^{12}$ In the notion of 
Andersen, ${ }^{12}$ healthcare use can be regarded as a measure of the realised, 'effective access' and is a commonly used measure to depict access and socioeconomic differences in access. ${ }^{13-18}$

Common policies and health system characteristics that are studied in the context of equity in access, equity in healthcare use and equity in health focus on macrolevel characteristics that are usually defined by national legislation. ${ }^{19-21}$ They include, among others, the national density of human resources for health, ${ }^{22}$ the level of national health expenditure,$^{23}$ the extent to which patients are obliged to copay medication and the presence of a gatekeeping system. ${ }^{21}$ A prominent policy example is represented by the US Medicaid programme, which provides health insurance mainly for people with low SEP, thereby targeting the access dimension of affordability by decreasing financial barriers to insurance coverage. ${ }^{24} 25$

Many high-income countries already perform well with respect to these indicators, with a relatively high level of national health expenditure and insurance coverage for the entire population. Yet, inequalities in the use of healthcare and health outcomes are still evident in all different types of healthcare systems. ${ }^{14}{ }^{26-28}$ Undoubtedly, these inequalities are of complex and multifactorial origin, and efforts from many policy sectors, including other than health, are required to improve the situation. ${ }^{3}$ However, with the past focus on macrolevel measures at a national level, the question arises whether and to what extent health systems of high-income countries may include unexploited potential to increase equity in health and healthcare use through adjustments in the health system at a smaller level. We refer to this level as 'mesolevel', as it lies below the just mentioned macrolevel, but has to be distinguished from the individual level, which is characterised by personal characteristics (cf. figure 1). ${ }^{29} 30$

While the macrolevel access characteristics of the health system have been studied extensively in the context of equity, the mesolevel access characteristics appear to have not been investigated as much. This might also reflect the challenge to accurately define a mesolevel of the health system. The meaning of the term in the health system's context differs by authors, ${ }^{29} 3132$ yet shares some basic similarities: they subsume characteristics of structures of the health system at a smaller than national scale, which usually are not directly part of the national health policy responsibility and are thus often defined by geographical region (eg, by county or district) and are referred to as 'regional' characteristics. Kramer et $a l^{29}$ highlight the importance of the health system's mesolevel, defining it ' $[\ldots]$ as the institutions and establishments that children and their families interact with on a regular basis'. Following this understanding, the local design of health services and the structure of the supply side, for example, the local density of physicians, are what determine the interaction between patients and the health system on a mesolevel. These contextual characteristics of the health system's mesolevel might influence access to healthcare, especially in terms of 'accomodation' (eg, appointment systems and office hours), 'accessibility' (eg, travel time, distance and cost) and 'availability' (eg, regional physician density), as termed by Penchansky and Thomas, ${ }^{10}$ and consequently the use of health services (cf. figure 1). Thus, the design of the healthcare system at this smaller scale of the mesolevel should not be overlooked when inequity in health and healthcare use is investigated.

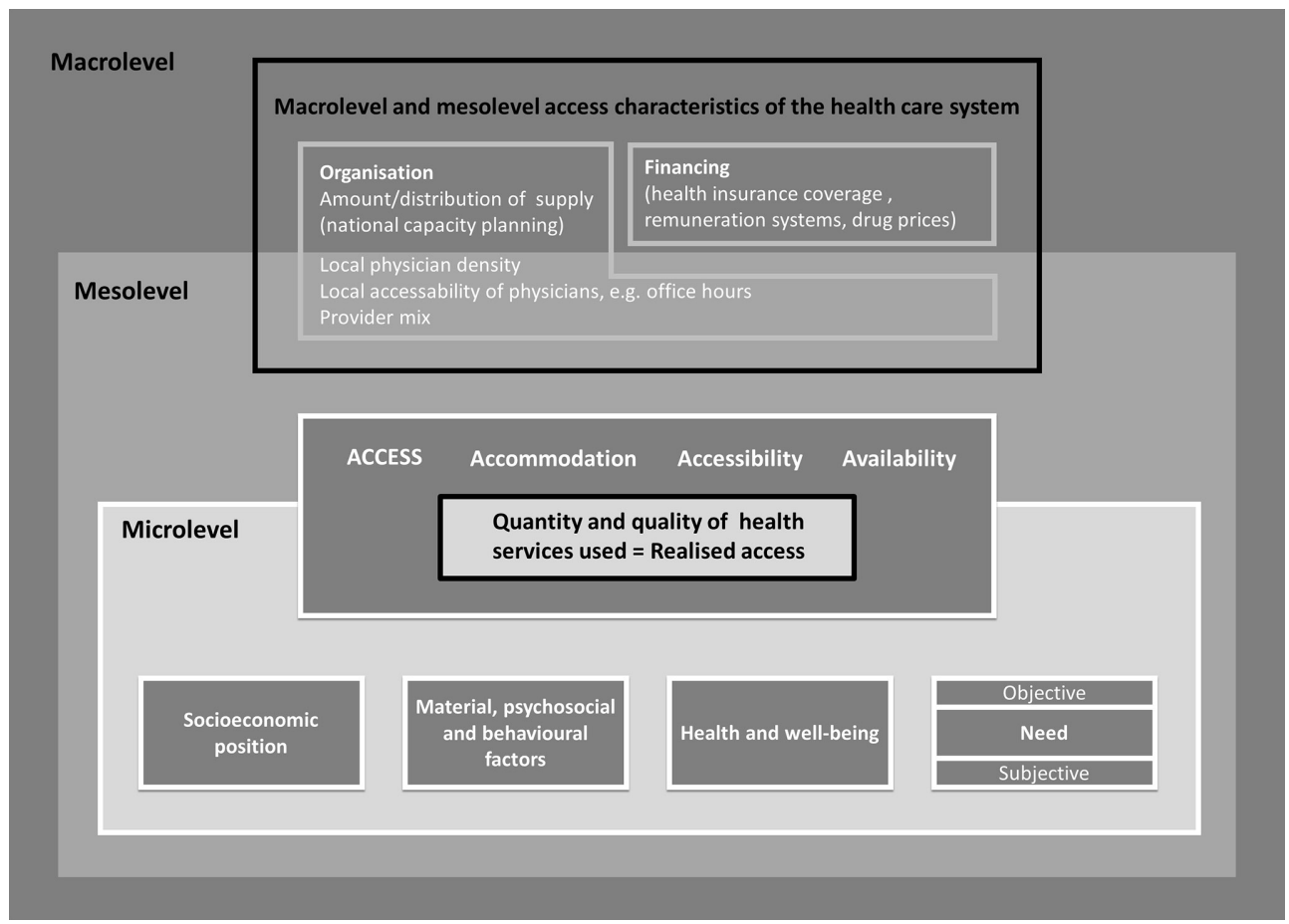

Figure 1 Framework to distinguish the macrolevel and mesolevel of the health system. 


\begin{tabular}{lll}
\hline Table 1 & Overview of inclusion and exclusion criteria \\
\hline $\begin{array}{lll}\text { Study } \\
\text { designs }\end{array}$ & $\begin{array}{l}\text { Original and peer-reviewed } \\
\text { research: }\end{array}$ & Exclusion \\
\hline Quantitative studies & Case studies \\
& & Comments, \\
& statements, \\
& replies, \\
& editorials \\
& Qualitative studies & Animal \\
& studies \\
& & Cell studies \\
& & Reviews
\end{tabular}

$\begin{array}{lll}\text { Population } & \text { No restriction } & \\ \text { Country } & \text { High-income countries } & \text { Studies } \\ \text { according to the United } & \text { Nations classification: } & \text { middle-income } \\ \text { mustralia, Austria, Belgium, } & \text { or low-income } \\ & \text { Bulgaria, Canada, Croatia, } & \text { countries } \\ & \text { Cyprus, Czech Republic, } \\ & \text { Denmark, Estonia, Finland, } \\ & \text { France, Germany, Greece, } \\ & \text { Hungary, Iceland, Ireland, } \\ & \text { Italy, Japan, Latvia, } \\ & \text { Lithuania, Luxembourg, } \\ & \text { Malta, Netherlands, New } \\ & \text { Zealand, Norway, Poland, } \\ & \text { Portugal, Spain, Slovakia, } \\ & \text { Slovenia, Sweden, } \\ & \text { Switzerland, UK, USA }\end{array}$

Determinants 1. Any measure used to of interest indicate the socioeconomic position, such as
- Educational status
- Income
- Deprivation
- Occupational status

\begin{tabular}{|c|c|c|}
\hline & $\begin{array}{l}\text { 2. Determinants of access at } \\
\text { the mesolevel, for example, } \\
\text { Physician density at a } \\
\text { regional level } \\
\text { Distance/travel time }\end{array}$ & $\begin{array}{l}\text { Determinants } \\
\text { of access at the } \\
\text { macrolevel, for } \\
\text { example, } \\
\text { Insurance } \\
\text { status } \\
\text { Provider } \\
\text { payment } \\
\text { schemes }\end{array}$ \\
\hline & - Consultation/office hours & \\
\hline Outcomes & $\begin{array}{l}\text { Any measure of individual } \\
\text { healthcare use }\end{array}$ & $\begin{array}{l}\text { Health status } \\
\text { Health- } \\
\text { related } \\
\text { behaviour } \\
\text { (physical } \\
\text { activity, } \\
\text { smoking) }\end{array}$ \\
\hline Languages & German, English & $\begin{array}{l}\text { Other } \\
\text { languages }\end{array}$ \\
\hline
\end{tabular}

Continued
Table 1 Continued

\begin{tabular}{lll}
\hline & Inclusion & Exclusion \\
\hline Publication & Published since 1 January & Published after \\
date & 2000 & 31 March 2020
\end{tabular}

${ }^{*}$ Reviews are not included, but the references will be screened for studies of interest.

It is therefore of interest to study and evaluate the role and impact of mesolevel access characteristics of the healthcare system in the relationship between SEP and health or healthcare use. To prepare such research, we have to identify the characteristics of the healthcare system that potentially impact on socioeconomic differences in access to healthcare at a mesolevel. To date, a comprehensive literature review of mesolevel access characteristics of the health system and their influence on socioeconomic inequity in healthcare use is missing. Therefore, the scoping review presented here aims to answer the following research question:

Which mesolevel access characteristics of the health system influence, moderate or aggravate socioeconomic inequality in healthcare use?

We review research investigating the impact of mesolevel characteristics of the health system on the correlation between SEP and healthcare use. Our aim is to gain a comprehensive overview on the mesolevel characteristics that have been researched in this context. Further, we seek to understand which of these characteristics play potentially a mediating, moderating or aggravating role with regard to socioeconomic inequity in healthcare use and should be focused on in future research.

The scoping review presented here will be undertaken in the context of the research unit FOR2723, 'Understanding the institutional context of health inequalities among young people. A life stage approach', which is funded by the German Research Foundation. ${ }^{33}$ Results of the scoping review will provide the basis for further analyses of one of the research unit's subprojects, focusing on the role of the healthcare system's mesolevel for socioeconomic inequality in healthcare use especially of young people.

This review adopts a broad approach and focuses on a population of any age, not only young people. Thus, we follow the idea that a health system characteristic that has been shown to influence socioeconomic inequality in healthcare use in a population of any age is most likely also to be relevant in the context of children and young people. However, as part of the narrative synthesis, the evidence will also be mapped for results that may be specific to children and adolescents.

\section{METHODS AND ANALYSIS}

We decided to conduct a scoping review because it represents a tool to determine the extent of the available evidence on a topic, to map the evidence in a full 
research area and to identify gaps in the evidence body. In general, scoping reviews address broader research questions. ${ }^{34}$ We conduct the scoping review according to guidance provided by the Preferred Reporting Items for Systematic Review and Meta-Analysis Protocols Extension for Scoping Reviews ${ }^{35}$ and the Joanna Briggs Institute. ${ }^{34}$

\section{Inclusion criteria}

We deduced three criteria that a study has to meet to be eligible for inclusion:

1. Measures of individual healthcare use must be reported.

2. Mesolevel determinants of access or mesolevel access characteristics of the health system must be reported or included in the analysis.

3. Measures of SEP must be included in the analysis.

In the following text, we describe the inclusion and exclusion criteria in more detail; an overview of these criteria is given in table 1 .

\section{Participants}

There will be no restriction on participant type in terms of age, gender or morbidity, although the specific aim of the project, to which this scoping review belongs, was to understand inequity in the healthcare use of children and adolescents. This review is intended to identify potentially relevant characteristics at the mesolevel of the health system that are worthy of thorough analysis with respect to this overall aim. The decision to include all populations follows the rationale that characteristics showing correlations with SEP and healthcare use at the mesolevel for any type of patient should be regarded as potential candidates for relevance to inequity in children and adolescents, too.

\section{Outcomes}

The outcomes of interest are measures of health services use, such as 'number of physician visits'. Studies investigating the use of healthcare are eligible for inclusion. In turn, this means that studies investigating solely health, health status or health behaviour as outcomes are excluded.

\section{Context and determinants of interest}

The focus of this review is on mesolevel access characteristics of the health system. Eligibility is therefore restricted to studies investigating access to health services at a mesolevel, such as 'regional average travel time to nearest physician' or 'local physician density'. Studies focusing on macrolevel determinants of access, such as payment schemes or insurance schemes that are decided on at a national level, will be excluded. Also, studies investigating specific health policies such as the sending of motivation letters will be excluded.

A further eligibility criterion constitutes the inclusion of a measure of SEP in the study or analysis, such as income or educational status.

\section{Types of studies}

In line with the characteristics of a scoping review, various quantitative study designs (eg, cross-sectional studies, prospective studies, cohort studies and case-control studies) but also qualitative ones are eligible for inclusion. Case, animal or cell studies will be excluded. Also, only original and peer-reviewed research is considered; commentaries, letters or statements will be excluded. The inclusion criterion regarding study types might be subjected to change, if findings are limited. In this case, also other types of research as grey literature or reports will be eligible. This would also imply adjustment of the extent of quality assessment of the evidence. Reviews are not eligible, although they will be screened for further relevant publications.

To increase comparability and transferability of the findings across countries, only publications studying populations from high-income countries (according to the category of 'developed economies' in the classification of the United Nations ${ }^{36}$ ) will be considered, as health systems, determinants of health services accessibility and socioeconomic disparities differ significantly between high-income, middle-income and low-income countries.

The search is restricted to articles written in English or German and published between 1 January 2000 and 31 March 2020.

\section{Search strategy}

The following four scientific literature databases will be searched: MEDLINE (via PubMed), Web of Science, Scopus and PsycINFO. The search strategy is composed of three thematic blocks of keywords, reflecting the three main inclusion criteria. These three blocks are connected with the Boolean Operator AND. The first block comprises keywords and phrases for 'healthcare use'. The second block describes the mesolevel context of the healthcare system and is split into two 'AND'-connected sub-blocks: a block containing OR-connected descriptors of regional factors and a block comprising a variety of synonyms for 'access' or specific access measures. The third block covers the 'SEP' and a variety of terms related to SEP. The defined keywords are searched within title and abstract fields. In addition, if applicable (PubMed and PsycINFO), appropriate Medical Subject Headings terms were searched too. An overview of all terms used is given in table 2.

Further, the search strategy comprises the restriction in terms of language and publication date, as detailed previously. Other inclusion/exclusion criteria (such as the country criterion) are applied within the selection process and are not reflected in the search strategy. The full search strategies for each database search are provided in the online supplemental appendix.

\section{Study selection process}

The selection process will consist of two screening stages: in the first step, title and abstract will be examined; in the second step, a full-text review will be conducted for those 
Table 2 Overview of descriptors used in search

\begin{tabular}{l} 
Search block \\
'Healthcare \\
Use': \\
\hline (descriptors \\
within search \\
block are \\
connected with \\
OR):
\end{tabular}

$\begin{array}{ll}\text { Health } & \text { Sub-block 'regional' Economic level } \\ \text { services } & \text { AND sub-block } \\ \text { underuse } & \text { 'access measures' }\end{array}$

\begin{tabular}{|c|c|c|}
\hline $\begin{array}{l}\text { Healthcare- } \\
\text { seeking } \\
\text { behaviour }\end{array}$ & & - Assets index \\
\hline $\begin{array}{l}\text { Health } \\
\text { services }\end{array}$ & Sub-block regional: & $\begin{array}{l}\text { Socioeconomic } \\
\text { position }\end{array}$ \\
\hline
\end{tabular}
needs and demand

\begin{tabular}{|c|c|c|c|}
\hline 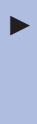 & $\begin{array}{l}\text { Delivery of } \\
\text { healthcare }\end{array}$ & $\begin{array}{l}\text { (descriptors within } \\
\text { search block are } \\
\text { connected with OR): }\end{array}$ & $\begin{array}{l}\text { Health status } \\
\text { disparities }\end{array}$ \\
\hline$\triangleright$ & $\begin{array}{l}\text { Medical } \\
\text { overuse }\end{array}$ & - Region & - Health equity \\
\hline 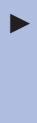 & $\begin{array}{l}\text { Health } \\
\text { services } \\
\text { overuse }\end{array}$ & - Neighbourhood & $\begin{array}{l}\text { Social } \\
\text { determinants of } \\
\text { health }\end{array}$ \\
\hline$\triangleright$ & $\begin{array}{l}\text { Health } \\
\text { services } \\
\text { overuse }\end{array}$ & - Geographical & $\begin{array}{l}\text { Healthcare } \\
\text { disparities }\end{array}$ \\
\hline 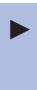 & $\begin{array}{l}\text { Healthcare } \\
\text { use }\end{array}$ & - Local & $\begin{array}{l}\text { Healthcare } \\
\text { inequalities }\end{array}$ \\
\hline 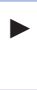 & $\begin{array}{l}\text { Health } \\
\text { services use }\end{array}$ & - Spatial & $\begin{array}{l}\text { Socioeconomic } \\
\text { position }\end{array}$ \\
\hline$\triangleright$ & $\begin{array}{l}\text { Physician } \\
\text { visits }\end{array}$ & Borough & $\begin{array}{l}\text { Socioeconomic } \\
\text { factors }\end{array}$ \\
\hline 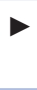 & $\begin{array}{l}\text { Paediatrician } \\
\text { visits }\end{array}$ & & - Social class \\
\hline 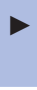 & $\begin{array}{l}\text { Children's } \\
\text { doctor visits }\end{array}$ & & $\begin{array}{l}\text { Socioeconomic } \\
\text { status }\end{array}$ \\
\hline 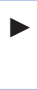 & $\begin{array}{l}\text { Baby doctor } \\
\text { visits }\end{array}$ & $\begin{array}{l}\text { Sub-block 'access } \\
\text { measures': }\end{array}$ & - Social gradient \\
\hline \multirow{7}{*}{\multicolumn{2}{|c|}{$\begin{array}{l}\text { Referral and } \\
\text { consultation }\end{array}$}} & $\begin{array}{l}\text { (descriptors within } \\
\text { search block are } \\
\text { connected with OR): }\end{array}$ & Inequity \\
\hline & & $\begin{array}{l}\text { Health services } \\
\text { accessibility }\end{array}$ & - Inequality \\
\hline & & $\begin{array}{l}\text { Access to } \\
\text { healthcare }\end{array}$ & - Gap \\
\hline & & $\begin{array}{l}\text { Availability of } \\
\text { health services }\end{array}$ & - Poverty \\
\hline & & - Travel times & - Deprivation \\
\hline & & - Travel distance & - Education \\
\hline & & Waiting times & $\begin{array}{l}\text { Educational } \\
\text { status }\end{array}$ \\
\hline
\end{tabular}

Continued

\begin{tabular}{|c|c|c|}
\hline $\begin{array}{l}\text { Search block } \\
\text { 'Healthcare } \\
\text { Use': }\end{array}$ & $\begin{array}{l}\text { Search block } \\
\text { 'Access' }\end{array}$ & $\begin{array}{l}\text { Search block } \\
\text { 'Socioeconomic } \\
\text { position' }\end{array}$ \\
\hline & - Hospital beds & - Income \\
\hline & - Physician density & - Family income \\
\hline & $\begin{array}{l}\text { Paediatrician } \\
\text { density }\end{array}$ & - Schooling \\
\hline & $\begin{array}{l}\text { General } \\
\text { practitioner } \\
\text { density }\end{array}$ & \\
\hline & - Healthcare supply & \\
\hline & Office hours & \\
\hline & $\begin{array}{l}\text { Consultation } \\
\text { hours }\end{array}$ & \\
\hline
\end{tabular}

Descriptors were searched in the title and abstract fields. Terms that were also used as Medical Subject Headings terms are denoted in italic font.

papers included after the first step. Both screening phases will be conducted independently by two reviewers (WS and AN) based on a set of previously defined inclusion and exclusion criteria (cf. table 1). The two reviewers agree in advance on a hierarchy of the inclusion/exclusion criteria to follow. The applicability of these and the hierarchy has been pretested in an exemplary test selection by both reviewers independently $(n=100)$. To determine inter-rater agreement between reviewers, we will calculate Cohen's Kappa after both phases. Disagreements will be resolved by discussion between the reviewers. In case consensus cannot be achieved, a third reviewer (LS) will take the final decision. The study selection process will be documented in detail.

The search will be performed on the websites of the mentioned databases. EndNote will be used to combine search results and to manage duplicates. Thereafter, search results will be imported to Rayyan, ${ }^{37}$ where the study selection process will be performed. Included studies will finally be imported to EndNote and/or Citavi for further steps, such as data extraction and results synthesis.

\section{Data extraction}

A predefined data extraction form will be used to extract relevant data from included studies. The data extraction form may be refined at the review stage, if necessary. It includes at least

- Title, author and year of publication

- Origin/country of origin

- Year of study execution

- Study design and relevant methods

- Aims of the study

- Population

- Healthcare use: how was it measured? Which type of health services? 
- Access: which mesolevel access characteristic of the health system was studied?

- SEP: how was SEP measured/operationalised?

- Key findings

Even though a critical appraisal in terms of study quality is not part of scoping reviews by default, we will extract basic characteristics related to study quality (for example the size of study population, limitations reported by authors, as well as further characteristics related to risk of bias depending on study design). Data extraction will be performed independently by two authors (WS and AN). Disagreements will be solved by discussion or, if no consensus can be reached, by a third author's decision (LS). During the data extraction process, multiple articles of the same study may be identified within the included studies. These will remain included, if they differ in the information they provide. Otherwise the most extensive version of the analysis is used.

\section{Data synthesis}

Data will be synthesised narratively, as high heterogeneity of studies is expected on account of the broad nature of the question. The aim is to provide a structured synthesis to reveal the main identified health system characteristics of interest. Subgroup analyses of specific population groups such as children and adolescents are planned.

\section{ETHICS AND DISSEMINATION}

No primary data are collected for this scoping review. Therefore, ethical approval is not required. This study protocol will be published in advance. The findings of the review will be published in an international peer-reviewed journal and may be presented at national or international conferences.

\section{Author affiliations}

${ }^{1}$ Department of Health Services Management, Ludwig-Maximilians-University Munich, Munich, Germany

${ }^{2}$ Chair of Health Economics, Technical University of Munich, Munich, Germany ${ }^{3}$ Department of Public Health, Brandenburg University of Technology CottbusSenftenberg, Senftenberg, Germany

${ }^{4}$ Department of Epidemiology and Health Monitoring, Robert Koch Institut, Berlin, Germany

${ }^{5}$ Mannheim Institute for Public Health, Social and Preventive Medicine, Medical Faculty Mannheim, University of Heidelberg, Mannheim, Germany

${ }^{6}$ Institute of Medical Sociology, Interdisciplinary Center for Health Sciences, Medical Faculty, Martin Luther University Halle-Wittenberg, Halle, Germany

${ }^{7}$ Institute for Medical Sociology, Centre for Health and Society, Medical Faculty, University of Düsseldorf, Düsseldorf, Germany

Contributors AN, WS and LS designed the presented scoping review, developed and implemented the search strategy, and drafted the manuscript. JS, BW, KD, IM, MR and ND critically revised the draft manuscript for important intellectual content. All authors read and approved the final version of the manuscript.

Funding This work was supported by the German Research Foundation grant number FOR2723 (project number 384210238). The individual grant number for the subproject is SU892/1-1.

Competing interests None declared.

Patient consent for publication Not required.

Provenance and peer review Not commissioned; externally peer reviewed.
Supplemental material This content has been supplied by the author(s). It has not been vetted by BMJ Publishing Group Limited (BMJ) and may not have been peer-reviewed. Any opinions or recommendations discussed are solely those of the author(s) and are not endorsed by BMJ. BMJ disclaims all liability and responsibility arising from any reliance placed on the content. Where the content includes any translated material, BMJ does not warrant the accuracy and reliability of the translations (including but not limited to local regulations, clinical guidelines, terminology, drug names and drug dosages), and is not responsible for any error and/or omissions arising from translation and adaptation or otherwise.

Open access This is an open access article distributed in accordance with the Creative Commons Attribution Non Commercial (CC BY-NC 4.0) license, which permits others to distribute, remix, adapt, build upon this work non-commercially, and license their derivative works on different terms, provided the original work is properly cited, appropriate credit is given, any changes made indicated, and the use is non-commercial. See: http://creativecommons.org/licenses/by-nc/4.0/.

\section{ORCID iDs}

Anna Novelli http://orcid.org/0000-0002-4600-0183

Wiebke Schüttig http://orcid.org/0000-0003-2669-2933

Benjamin Wachtler http://orcid.org/0000-0002-3959-5676

Katharina Diehl http://orcid.org/0000-0002-5408-652X

Irene Moor http://orcid.org/0000-0003-3245-5176

Nico Dragano http://orcid.org/0000-0002-0378-0757

Leonie Sundmacher http://orcid.org/0000-0001-6057-8363

\section{REFERENCES}

1 Wilkinson RG, Marmot M. Social determinants of health: the solid facts. 2nd edn. Copenhagen: WHO Regional Office for Europe, 2003.

2 Gilson L, Doherty J, Loewenson R. Challenging inequity through health systems: final report of the health systems knowledge network, 2007.

3 Costa-Font J, Hernández-Quevedo C. Measuring inequalities in health: what do we know? What do we need to know? Health Policy 2012;106:195-206.

4 Abiiro GA, De Allegri M, de AM. Universal health coverage from multiple perspectives: a synthesis of conceptual literature and global debates. BMC Int Health Hum Rights 2015;15:17.

5 Gilson L, Doherty J, Loewenson R. Challenging inequity through health systems. In: Commission on social determinants of health knowledge networks. Geneva: Improving equity in health by addressing social determinants, 2011: 197-230.

6 World health assembly resolution 58.33: sustainable health financing, universal coverage and social health insurance.

7 World Health Organization. Arguing for universal health coverage. Geneva, 2013.

8 Solar O, Irwin A. A conceptual framework for action on the social determinants of health: social determinants of health discussion paper 2 (policy and practice, 2007.

9 World Health Organization. Everybody's business - strengthening health systems to improve health outcomes: WHO's framework for action. Geneva, 2007.

10 Penchansky R, Thomas JW. The concept of access: definition and relationship to consumer satisfaction. Med Care 1981;19:127-40.

11 Allin S, Hernández-Quevedo C, Masseria C. Measuring equity of access to health care. In: Smith PC, ed. Performance measurement for health system improvement: experiences, challenges, and prospects. Cambridge: Cambridge University Press, 2009: 187-221.

12 Andersen RM. Revisiting the behavioral model and access to medical care: does it matter? J Health Soc Behav 1995;36:1-10.

13 Navarro-Rubio MD, Jovell AJ, Schor EL. Socioeconomic status and preventive health-care use by children in Spain. Am J Prev Med 1995;11:256-62.

14 Lampert T, Hoebel J, Kuntz B. Gesundheitliche Ungleichheit in verschiedenen Lebensphasen. Gesundheitsberichterstattung des Bundes 2017.

15 Janßen C, Frie KG, Dinger H. Der Einfluss von sozialer Ungleichheit auf die medizinische und gesundheitsbezogene Versorgung in Deutschland. In: Richter M, Hurrelmann K, eds. Gesundheitliche Ungleichheit: Verlag für Sozialwissenschaften, 2009: 149-65.

16 Simpson L, Zodet MW, Chevarley FM, et al. Health care for children and youth in the United States: 2002 report on trends in access, utilization, quality, and expenditures. Ambul Pediatr 2004;4:131-53.

17 Bremer P, Wübker A. Sozioökonomische Unterschiede in Der Inanspruchnahme von Haus- und Facharztleistungen in Deutschland. Prävention und Gesundheitsförderung 2013;8:15-21. 
18 Geyer S, Peter R, Siegrist J. Socioeconomic differences in children's and adolescents' hospital admissions in Germany: a report based on health insurance data on selected diagnostic categories. J Epidemiol Community Health 2002;56:109-14.

19 Beckfield J, Bambra C, Eikemo TA, et al. An institutional theory of welfare state effects on the distribution of population health. Soc Theory Health 2015;13:227-44.

20 Siegel M, Vogt V, Sundmacher L. From a conservative to a liberal welfare state: decomposing changes in income-related health inequalities in Germany, 1994-2011. Soc Sci Med 2014;108:10-19.

21 Wendt C. Einflussfaktoren von Gesundheitssystemen auf Gesundheit und gesundheitliche Ungleichheit. In: Richter M, Hurrelmann K, eds. Soziologie von Gesundheit und Krankheit. Wiesbaden: Springer VS, 2016: 211-26.

22 Anand S, Bärnighausen T. Human resources and health outcomes: cross-country econometric study. Lancet 2004;364:1603-9.

23 Bokhari FAS, Gai Y, Gottret P. Government health expenditures and health outcomes. Health Econ 2007;16:257-73.

24 Buchmueller T, Ham JC, Shore-Sheppard LD. The Medicaid program. In: Moffitt RA, ed. Economics of means-tested transfer programs in the United States. Chicago: University of Chicago Press, 2016: Vol. 1. 121-36.

25 Fossett JW, Perloff JD, Kletke PR, et al. Medicaid and access to child health care in Chicago. J Health Polit Policy Law 1992;17:273-98.

26 Hernández-Quevedo C, Jones AM, Rice N. Persistence in health limitations: a European comparative analysis. J Health Econ 2008;27:1472-88.

27 van Doorslaer E, Masseria C. Income-related inequality in the use of medical care in 21 OECD countries. OECD Health Working Papers, 2004. https://www.oecd.org/els/health-systems/31743034.pdf
28 van Doorslaer E, Masseria C, Koolman X, et al. Inequalities in access to medical care by income in developed countries. CMAJ 2006;174:177-83.

29 Kramer MR, Schneider EB, Kane JB, et al. Getting under the skin: children's health disparities as Embodiment of social class. Popul Res Policy Rev 2017;36:671-97.

30 Richter M, Dragano N. Micro, macro, but what about meso? The institutional context of health inequalities. Int $J$ Public Health 2018;63:163-4.

31 Salvador-Carulla L, Saldivia S, Martinez-Leal R, et al. Meso-level comparison of mental health service availability and use in Chile and Spain. Psychiatr Serv 2008;59:421-8.

32 Meyer T, Gutenbrunner C, Kiekens C, et al. ISPRM discussion paper: Proposing a conceptual description of health-related rehabilitation services. J Rehabil Med 2014;46:1-6.

33 Richter M, Dragano N, Lampert T. Understanding the institutional context of health inequalities among young people: study protoco for a multi-center research unit.: working paper 001. FOR2723. SocArXiv 2019.

34 Peters MDJ, Godfrey CM, Khalil H, et al. Guidance for conducting systematic scoping reviews. Int J Evid Based Healthc 2015;13:141-6.

35 Tricco AC, Lillie E, Zarin W, et al. PRISMA extension for scoping reviews (PRISMA-ScR): checklist and explanation. Ann Intern Med 2018;169:467-73.

36 United Nations. World economic situation and prospects 2019. statistical annex, 2019. Available: https://www.un.org/development/ desa/dpad/wp-content/uploads/sites/45/WESP2019_BOOK-ANNEXen.pdf [Accessed 19 May 2020]

37 Ouzzani M, Hammady H, Fedorowicz Z, et al. Rayyan-a web and mobile APP for systematic reviews. Syst Rev 2016;5:210. 